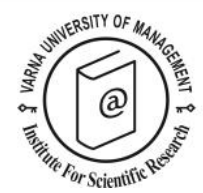

\title{
The viability of the travel and tourism competitiveness index as a reliable measure of destination competitiveness: the case of the Mediterranean region
}

\author{
Ivo Kunst ${ }^{1 *}$ and Neven Ivandić ${ }^{2}$
}

\footnotetext{
${ }^{1}$ Institute for tourism, Vrhovec 5, 10000 Zagreb, Croatia, E-mail: ivo.kunst@iztzg.hr, Tel: +38598354873

${ }^{2}$ Institute for tourism, Vrhovec 5, 10000 Zagreb, Croatia

* Corresponding author
}

\begin{abstract}
The Travel and Tourism Competitiveness Index (T\&TCI) seems to be the most used measure of a destination's competitiveness, even though the methodology underlying its calculation is characterized by numerous shortcomings. The viability of T\&TCI as a reliable measure of a country's competitive capability should stem from its ability to explain and/or predict the performance-related consequences of tourism activity within a destination. To check whether the T\&TCI can do that, a model has been constructed and tested on a sample of Mediterranean countries for the $2007-2017$ period. The analysis revealed that the change in the T\&TCI score often does not relate to a change in the performance-related indicators of tourism activity selected. Hence, the T\&TCI should not be regarded as a reliable measure of a destination's competitiveness.
\end{abstract}

Keywords: Destination competitiveness, Travel \& tourism competitiveness index, performance assessment, Mediterranean

Citation: Kunst, I. \& Ivandić, N. (2021). The viability of the travel and tourism competitiveness index as a reliable measure of destination competitiveness: the case of the Mediterranean region. European Journal of Tourism Research 27, 2704. 


\section{Introduction}

Under the influence of growing tourist demand on the global level (UNWTO, 2019), the proliferation of attractive tourist destinations across the world, and the ever greater segmentation of tourist interests (Gonzales \& Bello, 2002; Trauer, 2007; Sung et al., 2016; Dolnicar, 2019), the tourism market is characterized more and more by a growing struggle to ensure the interest/affinity of the (targeted) demand segments (Kunst, 2017). One should, therefore, not be surprised if the tourism destination competitiveness issue, as hitherto, remains one of the central preoccupations of governments, and policymakers worldwide, not only on the national, but also on the regional and/or local level (Mazanec et al., 2007; Dwyer at al., 2009; Hanafiah et al., 2015; Aral-Tur \& Kozak, 2015; Cucculelli \& Goffi, 2016; Abreu-Novais et al., 2016, Salinas Fernandez et al., 2020).

When it comes to factors that influence the competitiveness of a tourism destination, there is significant degree of compatibility in the viewpoints of the prominent tourism experts. This is, primarily, the result of numerous papers devoted not only to the elements that determine destination competitiveness (Hassan, 2000; Ritchie \& Crouch, 2000; Ritchie \& Crouch, 2003; Dwyer \& Kim, 2003; Heath, 2003; Enright \& Newton, 2004; Enright \& Newton, 2005; Ritchie \& Crouch, 2005; Mangion et al., 2005; Hall, 2007), but also to the abundance of work focusing primarily on the appropriate ways of monitoring and/or determining the level of tourism destination competitiveness already achieved (Ritchie et al., 2001; Dwyer \& Kim, 2003; Dwyer et al, 2004; Crouch, 2007; Kayar \& Kozak, 2010; Dupeyras \& MacCallum, 2013; Webster \& Ivanov, 2014; Abreu-Novais et al., 2015; Cvelbar et al., 2016; Mendola \& Volo, 2017; Guaita Martinez et al., 2020). Regardless of the abundance of relevant research, however, the academic community has, until recently, been unable to come to a consensus on not only how to measure a destination's competitiveness, but also on whether this is at all feasible (Mazanec \& Ring, 2011). This is mostly due to the fact that tourism destinations draw their competitiveness from different sets of variables that are difficult to compare, whether because of the distinctive structure of their product portfolios, their unique history, specific natural and/or cultural resources, or their tailor-made, development goals, including the means by which they are accomplished (Balan et al., 2009).

With the intention to compare the level of tourism competitiveness between different countries, and to create vital prerequisites for credible destination policies, in the year 2007 the World Economic Forum (WEF) introduced a composite index known as the Travel and Tourism Competitiveness Index (T\&TCI). The T\&TCI approach is currently being used to measure and compare destination competitiveness for more than 130 countries worldwide.

Bearing in mind that some of the theoretically important assumptions underlying the concept of destination competitiveness have been neglected and that there is a large range of methodological peculiarities in the calculation of the T\&TCI, the intention of this paper is to demonstrate that the T\&TCI score for an individual country by no means represents an unbiased and objective measure of its tourism sector competitiveness.

In accordance with the above stated goal, the paper is structured into six interrelated units. After the introduction, the second part, through an overview of relevant literature, provides further insight into the complexity of the destination competitiveness concept, and various facets that determine it. The third part explains the methodology behind the T\&TCI and its shortcomings, whereas the fourth part defines a methodological framework suitable to analyze the viability of the T\&TCI score as a proxy for destination competitiveness. The fifth part of the paper discusses the results of the conducted analysis. Finally, the sixth part of the paper, summarizes the findings and proposes refinements in the T\&TCI 
structure that might make it not only more relevant, but also more capable to explain the tourism activity, physical and financial, within a destination.

\section{Literature review}

Although the notion of competitiveness should, generally speaking, for the most part, be linked to the efficiency of the private sector in the use of basic production factors - labor and capital (Porter, 1980, 1990), the long-term growth of economic prosperity and well-being in a country depends predominantly on the government's ability to provide a stimulating macroeconomic environment that encourages private entrepreneurship, and creativity and maintains the necessary level of business optimism (Kunst, 2011). Therefore, in contrast to competitiveness at the level of the individual economic entity, which can be defined as the ability to conceive, produce, and supply the market with products and/or services whose price and non-price features represent a more attractive package than those offered by other companies (World Travel and Tourism Council, 1991), competitiveness at the level of a country, as well as at the level of a specific economic sector, can be defined as the ability to create and maintain an economic (business) environment that enables not only increased value creation, but also greater prosperity for the local population, respecting the available resources and measures of the economic policy (Garelli, 2006). In other words, competitiveness at the country level, as well as at the level of each of its economic sectors, is a result of the interaction of a large number of factors affecting: (i) the economic performance of the corporate sector, (ii) the efficiency of the public sector, (iii) the accessibility of adequate infrastructure and superstructure, as well as (iv) the level of entrepreneurial expectations (Garelli, 2006; Kunst, 2009).

The factors that determine competitiveness at the level of a business entity, as well as at a country level, seem to be a logical basis to approach the issue of tourism competitiveness. Unlike other (traditionally perceived) economic activities characterized by the principles of transparency, inclusivity, and exclusivity (Kunst, 2009), and resulting in broadly recognizable final products (furniture, yachts, books, food), tourism industry is characterized by the fact that the "tourism product" represents a composite category which consists of various individually created and marketed (service) products (Buhalis, 200o; Murphy et al., 2000; Beritelli et al., 2007; Rodrıguez-Dıaz, \& Espino-Rodrıguez, 2008; Morrison, 2013; Ivanov \& Ivanova, 2016; Weldearegay, 2017). Further, since it encompasses a variety of mutually dependent products and/or services that are being simultaneously brought to market by individual entrepreneurs, as well as various public entities, tourism competitiveness at a national (regional, local) level is largely conditional upon the depth and/or width of its tourism value chain (Yilmaz \& Bititci, 2006; Weiermeier, 2006; Song et al., 2013).

The second 'diferentia specifica' of the tourism business refers to the fact that each tourism product is always related with a specific location, be it a country, region or city (Urry 1990; Crouch 1999; Ateljevic 2000; Pritchard \& Morgan 2001; Gnoth 2007). Regardless of the multitude of other, more or less compatible definitions (Pearce, 1989; Leiper, 1995; Buhalis, 2000; Baerenholdt et al. 2004; Hall \& Page, 2006), it can be said that a tourism destination is a well-defined geographical area that can be actively managed, and within which the potential visitors (tourists) enjoy various types of tourist experiences that are the result of creative interactions of various stakeholders from both the private and the public sector (Haugland et al., 2011; Morisson, 2013). Following the concept of a tourism destination, its competitiveness can be defined as "the ability of an area to optimize its attractiveness to, both residents and non-residents, to deliver high quality, innovative, and attractive tourism services... and to generate market share growth in the domestic, and global markets, while ensuring efficient and sustainable use of the available tourism resources" (Dupeyras \& MacCallum, 2013, pp. 14). 
In other words, the achievement of a sustainable destination competitiveness should pave the way not only to the increase in the real income of the destination's citizens, but to the prosperity and the wellbeing of the society as a whole mostly due a gain in tourism related earnings by means of providing satisfying experiences (Crouch \& Ritchie, 1999; Dwyer \& Kim, 2003; Dwyer et al, 2004; Mazanec \& Ring, 2011; Croes \& Kubickova, 2013, Abreu-Novais et al., 2018; Croes \& Semrad, 2018).

Because tourism competitiveness takes into account several dimensions, the economic, socio-cultural, environmental, and political (Ritchie \& Crouch, 200o), a destination can achieve competitiveness only if a suitable institutional framework is established, capable of monitoring, controlling and increasing the product quality of different tourism related entrepreneurs on one hand, as well as of protecting the resource base of the destination on the other (Goeldner et al., 200o; Goffi, 2013; Cuculelli \& Goffi, 2016; Abreu-Novais et al., 2018).

Since the supply side of the tourism industry has all the distinctive features of monopolistic competition (Kunst, 1998), a destination's competitiveness on the global market stems predominantly from the created quality perception of the available tourist experiences it can offer, as well as from the associated benefits delivered to the consumers, as compared to all the other tourism destinations (Tomljenović \& Kunst, 2014). Therefore, it can be concluded that the competitiveness of any tourism destination stems from its ability to differentiate itself, efficiently and successfully, from the potential competition. This can be achieved predominantly by offering unique and authentic tourist experiences (Pine \& Gilmore, $1998,1999)$. In this regard, further, it may be assumed that the competitiveness of a tourism destination will be less dependent on a country's generally perceived socio-economic status, and the degree of (social) welfare achieved, as might be derived from the assumptions underlying the so-called "rational expectations" paradigm (Sargent \& Lucas, 1981). At the same time, the uniqueness and intensity of available tourist experiences are becoming more influential in attracting tourists. In other words, the fact that a tourism destination is more infrastructurally equipped, more environmentally regulated, more advanced in healthcare and education provision and less risky in terms of personal safety, does not necessarily mean that such a destination is more competitive in the sense that it is capable of permanently increasing its market share, or generating higher levels of tourist expenditure per capita (Kunst, 2009).

Due primarily to their mostly conceptual nature, the theoretical models addressing the elements that determine a destination's competitiveness (Hassan, 2000; Ritchie \& Crouch, 2000; Dwyer \& Kim, 2003; Heath, 2003; Enright \& Newton, 2004; Mangion et al., 2005; Hall, 2007; Goffi, 2013; 2015; Cvelbar et al. 2016; Abreu-Novais et al., 2018) proved to be unsuitable for practical use, due predominantly to their inability to provide an effective way to measure a destination's competitive capacity. As a result, and in an attempt to capture its complex nature, a destination's competitiveness is, nowadays, conventionally being measured mostly through (composite) indices (Croes \& Kubickova, 2013; Mendola \& Volo 2017; Hanafiah \& Zulkilfly, 2019; Salinas Fernandez et al. 2020). The most popular composite index used for the measurement of destination competitiveness is the Travel and tourism competitiveness index T\&TCI (Dwyer et al., 2011; Ivanov \& Ivanova, 2016).

The use of T\&TCI as a proxy of a destination's competitiveness has been increasingly used in academic areas as well. Namely, it has recently been used to determine: (i) which factors affect a country's competitive position the most (Bednarova et al., 2018), (ii) if tourism stimulates a destination's economic growth (Webster \& Ivanov, 2014), (iii) if hotel chains presence within a destination improve a destination's overall competitiveness (Ivanova \& Ivanov, 2016). It has also been applied as one of the variables determining tourism arrivals in gravity models (Marti \& Puertas, 2016). 


\section{The Travel and Tourism Competitive Index - approach and shortcomings}

In order to cut through the various complexities associated with most of the conceptual work related to destination competitiveness, and in order to provide a pragmatic way for measuring it, the World Economic Forum (WEF, 2008) introduced the Travel and Tourism Competitive Index (T\&TCI) as a measure of a destination's competitive capability. The T\&TCI is a composite index that, in a linear and mechanical way, addresses the complex issue of tourism competitiveness. Based predominantly on Porter's idea that productivity is the core determinant of competitiveness (Porter, 1990), and upgrading the similar previous approach of the World Travel and Tourism Council (Gooroochurn \& Sugiyarto, 2005), the T\&TCI score is intended to represent an aggregate measure of a country's tourism competitiveness.

The index itself is based on a relatively large number of indicators. Although the majority of the indicators are of a quantitative nature, and are derived from internationally available independent data sources (such as UNESCO, UNWTO, WTTC, IATA, etc.), a relatively large number of indicators are based on the World Economic Forum's Executive Opinion Survey. These indicators represent business leaders' opinions on various issues for which data from 'hard' sources are usually unavailable, but which are considered to be relevant for the competitiveness of any tourism destination (Squalli et al, 2008). All indicators are allocated to one of the 14 competitiveness pillars (World Economic Forum 2007, 2009, 2011, 2013, 2015, 2017, 2019.).

Throughout the period from 2007 to 2019 , the methodological approach to T\&TCI calculation has not changed significantly. Nevertheless, the changes that have been made refer to:

- The addition of a new pillar (in 2009), entitled 'Affinity for Travel \& Tourism';

- Gradual increase in total number of indicators (from 58 in 2007 to 90 in 2015 and onwards) resulting in the change of the T\&TCI structure (due to the disproportionate increase in the number of quantitative as opposed to qualitative indicators);

- Minor changes in data sources; and

- The new way of pillar aggregation into sub-indices (in 2015) to ensure the indices cover more interrelated topics/pillars.

Notwithstanding the changes in the aggregation of individual pillars, as well as the disproportionate growth of the number of (mostly quantitative) indicators, the basic calculation principles of the T\&TCI have not changed over the observed 12-year period. Namely, the calculation itself involves two steps:

- Step I - data collection for each of the indicators, in which the qualitative (survey based) indicators are rated on a scale from 1 (worst possible) to 7 (best possible). On the other hand, the (absolute) values of the quantitative indicators are also being 'normalized' on a scale of 1 (worst possible) up to 7 (best possible) to ensure comparability with qualitative indicators,

- Step II - calculation of average scores for each of the 14 pillars, their aggregation into the subindices, and the final calculation of the T\&TCI for each country involved. The calculation of the score for each of the pillars, the score for each of the sub-indices, as well as the aggregate score for each of the countries, namely the T\&TCI, is based on unweighted averages.

Although T\&TCI formally addresses the issue of tourism destination competitiveness measurement and comparison, the calculations involved have a number of methodological problems regarding not only the choice of relevant indicators, but also the objectivity of ratings, as well as the comparison of the results (Crouch, 2007; Mazanec \& Ring, 2011; Wu, Lan \& Lee, 2012; Ivanov \& Webster, 2013; Mendola \& Volo, 2017; Croes \& Semrad, 2018; Guita Martinez et al., 2020; Magrini \& Grassini, 2020). 
Table 1. Competitiveness pillars, number, and type of TETCI indicators, $2007-2019$

\begin{tabular}{|c|c|c|c|c|}
\hline \multirow{2}{*}{ Sub-indices and pillars } & \multicolumn{2}{|c|}{2007} & \multicolumn{2}{|c|}{2013} \\
\hline & $\begin{array}{l}\text { No of } \\
\text { variables }\end{array}$ & $\begin{array}{l}\text { Variable } \\
\text { mix }^{*}\end{array}$ & $\begin{array}{l}\text { No of } \\
\text { variables }\end{array}$ & $\begin{array}{l}\text { Variable } \\
\text { mix }^{*}\end{array}$ \\
\hline
\end{tabular}
1st pillar: Policy rules and regulations

$\begin{array}{llll}5 & 3 \mathrm{~S}+2 \mathrm{H} & 9 & 4 \mathrm{~S}+5 \mathrm{H} \\ 3 & 3 \mathrm{~S} & 7 & 3 \mathrm{~S}+4 \mathrm{H} \\ 3 & 3 \mathrm{~S} & 4 & 3 \mathrm{~S}+1 \mathrm{H} \\ 4 & { }_{1 \mathrm{~S}+3 \mathrm{H}} & 4 & 4 \mathrm{H} \\ 4 & { }_{2} \mathrm{~S}+2 \mathrm{H} & 5 & 2 \mathrm{~S}+3 \mathrm{H}\end{array}$

2nd pillar: Environmental sustainability

3rd pillar: Safety and security

4th pillar: Health and

hygiene

5th pillar: Prioritization of

Travel \& Tourism

Sub-index B: T\&T business environment and infrastructure

\begin{tabular}{|c|c|c|c|c|}
\hline $\begin{array}{l}\text { 6th pillar: Air transport } \\
\text { infrastructure }\end{array}$ & 6 & $2 \mathrm{~S}+4 \mathrm{H}$ & 7 & ${ }_{2} \mathrm{~S}+5 \mathrm{H}$ \\
\hline $\begin{array}{l}\text { 7th pillar: Ground transport } \\
\text { infrastructure }\end{array}$ & 4 & $4 \mathrm{~S}$ & 5 & $4 \mathrm{~S}+1 \mathrm{H}$ \\
\hline $\begin{array}{l}\text { 8th pillar: Tourism } \\
\text { infrastructure }\end{array}$ & 3 & $3 \mathrm{H}$ & 3 & $3 \mathrm{H}$ \\
\hline 9th pillar: ICT infrastructure & 3 & $1 \mathrm{~S}+2 \mathrm{H}$ & 7 & $2 \mathrm{~S}+5 \mathrm{H}$ \\
\hline $\begin{array}{l}\text { 1oth pillar: Price comp. in } \\
\text { the T\&T industry }\end{array}$ & 4 & $1 \mathrm{~S}+3 \mathrm{H}$ & 5 & $1 \mathrm{~S}+4 \mathrm{H}$ \\
\hline
\end{tabular}

Sub-index C: T\&T human, cultural, and natural resources

\begin{tabular}{lllll} 
11th pillar: Human resources & 11 & $5 \mathrm{~S}+6 \mathrm{H}$ & 10 & $6 \mathrm{~S}+4 \mathrm{H}$ \\
$\begin{array}{l}\text { 12th pillar: Affinity for Travel } \\
\text { \& Tourism }\end{array}$ & - & - & 4 & $3 \mathrm{~S}+1 \mathrm{H}$ \\
$\begin{array}{l}\text { 13th pillar: Natural resources } \\
\text { 14th pillar: Cultural }\end{array}$ & 3 & $2 \mathrm{~S}+1 \mathrm{H}$ & 5 & ${ }_{1} \mathrm{~S}+3 \mathrm{H}$ \\
resources & 5 & $1 \mathrm{~S}+4 \mathrm{H}$ & 4 & $4 \mathrm{H}$ \\
\hline Total & $\mathbf{5 8}$ & $\mathbf{2 8 S}+\mathbf{3 0 H}$ & $\mathbf{7 9}$ & $\mathbf{3 1} \mathbf{S}+\mathbf{4 8 H}$ \\
\hline
\end{tabular}

\section{Sub-indices and pillars}

Sub-index A: Enabling Environment 1st pillar: Business environment $12 \quad 7 \mathrm{~S}+5 \mathrm{H}$ 2nd pillar: Safety and security $\quad 5 \quad 3 \mathrm{~S}+2 \mathrm{H}$ 3rd pillar: Health and hygiene $6 \quad 6 \quad 6 \mathrm{H}$ 4th pillar: Human Resources and Labor Market $96 \mathrm{~S}+3 \mathrm{H}$ 5th pillar: ICT Readiness $8 \quad 3 \mathrm{~S}+5 \mathrm{H}$ variables $\mathrm{mix}^{*}$
No of Variable

\begin{tabular}{|c|c|c|}
\hline \multicolumn{3}{|c|}{$\begin{array}{c}\text { Sub-index B: T\&T Policy \& Enabling } \\
\text { Conditions }\end{array}$} \\
\hline $\begin{array}{l}\text { 6th pillar: Prioritization of } \\
\text { Travel and Tourism }\end{array}$ & 6 & $2 \mathrm{~S}+4 \mathrm{H}$ \\
\hline $\begin{array}{l}\text { 7th pillar: International } \\
\text { Openness }\end{array}$ & 3 & $3 \mathrm{H}$ \\
\hline $\begin{array}{l}\text { 8th pillar: Price } \\
\text { Competitiveness }\end{array}$ & 4 & $4 \mathrm{H}$ \\
\hline $\begin{array}{l}\text { 9th pillar: Environmental } \\
\text { Sustainability }\end{array}$ & 10 & ${ }_{3} \mathrm{~S}+7 \mathrm{H}$ \\
\hline
\end{tabular}

\section{Sub-index C: Infrastructure}

1oth pillar: Air Transport

Infrastructure

$6 \quad 1 \mathrm{~S}+5 \mathrm{H}$

11th pillar: Ground and Port

Infrastructure

$7 \quad 4 \mathrm{~S}+3 \mathrm{H}$

12th pillar: Tourist Service

Infrastructure

$4 \quad{ }_{1} \mathrm{~S}+3 \mathrm{H}$

Sub-index D: Natural \& Cultural Resources

13th pillar: Natural Resources

$5 \quad 1 \mathrm{~S}+4 \mathrm{H}$

14th pillar: Cultural Resources

\& Business Travel

$5 \quad 5 \mathrm{H}$

\section{Total}

${ }^{*} \mathrm{H}$ - variables based on hard data; $\mathrm{S}$ - variables based on survey data.

Source: World Economic Forum 2007, 2013; 2015-2019

Regarding the choice of relevant indicators issue, the problems relate mostly to:

- In defining most of the competitiveness indicators, the T\&TCI approach does not sufficiently rely on the findings and /or suggestions of the theoretical destination competitiveness models (Mazanec et al, 2007; Crouch 2007, Mazanec \& Ring 2011; Croes \& Kubickova, 2013; Mendola \& Volo, 2017). As a result, the cause and effect relationship connecting the multitude of critical indicators is disregarded (Mazanec et al, 2007; Croes \& Semrad, 2018) due to which the T\&TCI seems more a systematic collection 
of data than a model that reveals clear testable associations among variables (Croes \& Kubickova, 2013). Further, using the wrong set of indicators can bring about inaccurate results and lead to ill-informed decisions that might jeopardize the destination's long-term viability (Croes, 2011).

- T\&TCI does not include many of the potentially relevant destination competitiveness indicators; despite the fact that (some of) the most relevant theoretical models propose the inclusion of more than 150 indicators (Richie \& Crouch, 2003; Dwyer \& Kim 2003), the T\&TCI is based only on 90 indicators. In this regard, one needs to point out especially the exclusion of indicators related to: (i) the intensity of rivalry within a destination, (ii) the availability and /or quality of the gastronomy, (iii) the accessibility and/or quality of entertainment and/or shopping facilities, as well as (iv) the degree of destination planning and/or management. In addition, the T\&TCI completely avoids the issue of guest satisfaction-related indicators.

In terms of methodological shortcomings that affect the objectivity of the countries' rating, one should primarily point out the following issues:

- Relative importance of indicators - the T\&TCI approach assumes that all go indicators, as well as all 14 pillars, have the same importance for a destination's competitiveness. This cannot be a realistic assumption (Wu et al., 2012; Cvelbar et al., 2016; Weldearegay, 2017; Croes \& Semrad, 2018; Guita Martinez et al., 2020; Magrini \& Grassini, 2020). Further, because of a different number of indicators per each pillar, arbitrary weights are indirectly included in the calculation methodology as well. In other words, the higher the number of indicators used to calculate the score for a pillar, the lower is their overall importance for the total T\&TCI score. The same is true for the calculation of sub-indices. Finally, it is also questionable whether all the pillars, as well as the sub-indices are equally important for a certain destination's competitiveness.

- Aggregation of the quantitative and survey-based indicators; since the ratings of individual pillars are obtained by aggregating both hard and soft indicators, with hard indicators being normalized beforehand, the methodology prefers the countries that achieve better results in the sphere of hard indicators. The reason for this has a lot to do with the fact that hard indicators are scattered (more or less) evenly throughout the scale from 1 to 7 , whereas the soft indicators take extreme values of 1 or 7 only as an exception (Crouch 2007; Mazanec \& Ring, 2011; Weldearegay, 2017; Magrini \& Grassini, 2020).

- T\&TCI composition; the T\&TCI assessment of tourism competitiveness of a country is based, to a large extent, on the indicators reflecting overall socio-economic development, which serves the interests of all highly economically developed countries (Wu, Lan, \& Lee, 2012). In this regard, it tends to rank more economically more advanced destinations higher than destinations in lower stages of socio-economic development (Kester \& Croce, 2011; Marti \& Puertas, 2017; Hanafiah \& Zulkilfy, 2019)

- T\&TCI approach totally neglects the experiential component of the destination's competitiveness (Kunst, 2009). Namely, regardless of the fact that a certain destination may, in comparison to some other destination, be regarded as price advantageous, infrastructurally more equipped, legally better regulated, educationally superior and/or safer to live in, this does not necessarily mean that such a destination will be more competitive and, as a result, attract more visitors and/or end up with more tourism related receipts than a destination that is quite remote, somewhat exotic, still not fully discovered by the mainstream holidaymaker, and, in general, underdeveloped in terms of the availability of infra and superstructure.

Finally, in terms of comparability of the results, and, hence, the ranking of countries according to the degree of their tourism competitiveness, the following limitations of the T\&TCI methodology should be pointed out:

- Data availability - the data for the calculation of individual quantitative indicators are not always readily available for all the countries covered by the survey. In calculating the competitiveness 
pillars for countries for which not all the indicators can be determined/assessed (Jackman et al., 2011; Croes \& Kubickova, 2013), the T\&TCI methodology calculates the value of the pillar according to a smaller number of indicators. This results in an overestimation or underestimation of the score of that particular pillar.

- Data reliability - since it is not possible to obtain hard data for all countries from the same statistical source, and/or since some of these data are not compiled in the same way, various compromises have to be made. This compromises the quality of the analysis.

- Comparability of countries with different product portfolios and/or development goals (depending on the achieved level of economic/tourism development); the T\&TCI approach implies a unique set of tourism development goals for all countries, which boils down to the maximation of tourist arrivals and/or tourism related receipts (Lall, 2001; Crouch, 2007; Croes \& Kubickova, 2013). In other words, T\&TCI systematically disregards the possibility that different countries might have different tourism development goals, resulting from the differences in their market position, and/or their development preferences. For example, highly saturated tourist countries such as Malta, for instance, might choose to opt for a decline in tourism overnights in order to upgrade guest satisfaction as well as average per capita spending. Such a policy action would, under the T\&TCI methodology, imply a decrease in competitiveness.

- Reliability of qualitative indicators - since the T\&TCI approach is to a large amount conditional upon the data obtained from the Executive Opinion Survey, it totally disregards the fact that the respondents in each country might have: (i) different access to information, (ii) different degrees of understanding of the global trends in technology development and/or quality standards, (iii) different levels of business optimism, but also (iv) different motivations to participate in the survey in the first place (Lall, 2001; Crouch, 2007). Even if the scores obtained by the survey objectively represent the situation in one country, this does not, in any way whatsoever, imply that the information/objectivity of the survey in other countries is equally representative (Kunst, 2009). Therefore, given the varying levels of objectivity in various countries, the reliability of international comparisons is questionable.

\section{Methodological framework}

T\&TCI is expected to explain and predict the performance-related consequences of tourism activity (Mazanec et al, 2007). In other words, T\&TCI does not meet its objectives unless its overall score exhibits a satisfactory level of association with some measurable, statistically available and widely used measure of tourism performance (Mazanec \& Ring, 2011; Assaf \& Tsionas, 2015; Dwyer et al., 2016; Croes \& Semrad, 2018).

To test whether the T\&TCI score exhibits a satisfactory level of association with widely used measures of tourism performance, a three-step methodological approach has been deployed. The first step is related to the specification of the geographical area of interest. The second step is related to the selection of viable, performance-based, aggregates of tourism activity that exhibit a strong positive correlation to the T\&TCI score as well. In the third step, based on these aggregates, the model for the analysis has been constructed.

\section{Geographical context: Mediterranean}

The analysis has been conducted on the sample of Mediterranean countries for the $2007-2017$ period (Table 3). Mediterranean countries have been chosen since the Mediterranean represents one of the most visited regions worldwide, but also due to the similarities in their tourism products/demand characteristics. In this way, the impact of changes in customer preferences or economic trends across different regions has been minimized. However, some countries, namely Libya, Syria and Monaco, have been excluded from the analysis. In the case of Libya and Syria, this is due to the political instabilities 
to which they were exposed during the analyzed period. Monaco, on the other hand, is not included in the T\&TCI calculation.

Table 3. Mediterranean countries included in the analysis*

\begin{tabular}{|c|c|c|c|c|}
\hline \multirow{2}{*}{ Countries** } & \multicolumn{4}{|c|}{ Analyzed time periods } \\
\hline & 2009-2011 & 2011-2013 & $2013-2015$ & $2015-2017$ \\
\hline Spain & $\mathrm{X}$ & $\mathrm{X}$ & $\mathrm{X}$ & $\mathrm{X}$ \\
\hline France & $\mathrm{X}$ & $\mathrm{X}$ & $\mathrm{X}$ & $\mathrm{X}$ \\
\hline Italy & $\mathrm{X}$ & $\mathrm{X}$ & $\mathrm{X}$ & $\mathrm{X}$ \\
\hline Turkey & $\mathrm{X}$ & $\mathrm{X}$ & $\mathrm{X}$ & $\mathrm{X}$ \\
\hline Greece & $\mathrm{X}$ & $\mathrm{X}$ & $\mathrm{X}$ & $\mathrm{X}$ \\
\hline Croatia & $\mathrm{X}$ & $\mathrm{X}$ & $\mathrm{X}$ & $\mathrm{X}$ \\
\hline Egypt & $\mathrm{X}$ & $\mathrm{X}$ & $\mathrm{X}$ & $\mathrm{X}$ \\
\hline Morocco & $\mathrm{X}$ & $\mathrm{X}$ & $\mathrm{X}$ & $\mathrm{X}$ \\
\hline Lebanon & - & $\mathrm{X}$ & $\mathrm{X}$ & $\mathrm{X}$ \\
\hline Israel & $\mathrm{X}$ & $\mathrm{X}$ & $\mathrm{X}$ & $\mathrm{X}$ \\
\hline Cyprus & $\mathrm{X}$ & $\mathrm{X}$ & $\mathrm{X}$ & $\mathrm{X}$ \\
\hline Slovenia & $\mathrm{X}$ & $\mathrm{X}$ & $\mathrm{X}$ & $\mathrm{X}$ \\
\hline Albania & $\mathrm{X}$ & $\mathrm{X}$ & $\mathrm{X}$ & $\mathrm{X}$ \\
\hline Malta & $\mathrm{X}$ & $\mathrm{X}$ & $\mathrm{X}$ & $\mathrm{X}$ \\
\hline Tunisia & $\mathrm{X}$ & - & - & $\mathrm{X}$ \\
\hline Montenegro & $\mathrm{X}$ & $\mathrm{X}$ & $\mathrm{X}$ & $\mathrm{X}$ \\
\hline Bosnia and Herzegovina & $\mathrm{X}$ & $\mathrm{X}$ & - & - \\
\hline Algeria & $\mathrm{X}$ & $\mathrm{X}$ & $\mathrm{X}$ & $\mathrm{X}$ \\
\hline $\begin{array}{l}\text { \# of analyzed Mediterranean } \\
\text { countries/period }\end{array}$ & 17 & 17 & 16 & 17 \\
\hline
\end{tabular}

* 'X' refers to availability of data, whereas '-' refers to data unavailability

** the country order reflects the size of their inbound tourism expenditures in year 2017

Source: authors on the base of data presented by the World Economic Forum (2009, 2011, 2013, 2015, 2017), and

UNWTO $(2013,2019)$

Competitive capability vs performance-based aggregates of tourism activity

Regarding the overall T\&TCI score as a reliable measure of a destination's competitive capability (Dwyer at al., 2011; Dupeyras \& MacCallum, 2013; Webster \& Ivanov, 2014; Marti \& Puertas, 2016), one needs to define representative performance-based proxies of destination competitiveness. In this regard, and following the recommendations of Ritchie \& Crouch (2003); Mazanec \& Ring (2011), and Magrini \& Grassini (2020), inbound tourism expenditures and international tourism arrivals both seem to be viable measures of a destination's tourism performance in any given period. That is, both of these aggregates, especially over the long run, not only incorporate the changes in market shares, but also, implicitly, indicate the changes in the attractiveness of the destination's overall tourism offer, as well as the overall changes in guest satisfaction level.

To check the appropriateness of the selected tourism performance aggregates, both were correlated with the T\&TCI score for the Mediterranean as a region. The calculated correlation coefficients for the 2007-2017 period in both cases (Table 4) indicate a positive and growing linear correlation. The correlation is especially strong in years 2015 and 2017, most likely due to T\&TCI methodological improvements over time. 
Table 4. International tourism arrivals and inbound tourism expenditures correlation coefficients with the overall TETCI score for the Mediterranean region

\begin{tabular}{lcc}
\hline & $\begin{array}{l}\text { International tourism arrivals } \\
\text { and the T\&TCI score } \\
\text { correlation coefficients }\end{array}$ & $\begin{array}{l}\text { Inbound tourism expenditures } \\
\text { (in US\$) } \\
\text { correlation the T\&TCI score }\end{array}$ \\
\hline 2007 & 0.456 & 0.481 \\
2009 & 0.613 & 0.643 \\
2011 & 0.631 & 0.656 \\
2013 & 0.681 & 0.654 \\
2015 & 0.842 & 0.834 \\
2017 & 0.875 & 0.869 \\
\hline
\end{tabular}

${ }^{*}$ Linear correlation coefficients have been calculated using EXCEL for Office 365

Source: Authors based on data presented by the World Economic Forum (2009, 2011, 2013, 2015, 2017), and UNWTO $(2013,2019)$

Since the positive correlation between T\&TCI as a measure of a destination's competitive capability and selected tourism performance aggregates has been determined as viable, it was possible to use them for the specification of indicators suitable for analyzing the ability of the T\&TCI score to explain relative changes in the competitive position of a destination: since destination competitiveness needs to be viewed in a dynamic context, reflecting a change in its market position over time, and in a relative context, reflecting a change in its market position relative to other countries (Ritchie \& Crouch, 2003), the analysis itself needs to combine time series data (period from 2007 to 2017) and cross-section data (Mediterranean countries).

\section{Model characteristics}

Based on these arguments, and with the intention of neutralizing the possible impacts of: (i) country size in terms of inbound tourism volume, (ii) international tourism/economic movements outside the Mediterranean region, and the (iii) units of measurement issue, three indicators have been developed (Table 5).

The ability of the T\&TCI score, based on the specified indicators, to explain changes in the competitive position of a destination is envisaged by a graphical representation of ordered pairs of the T\&TCI score and one of the performance related indicators for a particular country within the Mediterranean. The ordered pairs of T\&TCI score and performance related indicators are defined as:

- the rate of change in a country's overall T\&TCI score, and the rate of change of a country's market share of international tourism arrivals. The model establishes the association between the rate of change in international tourism arrivals in time ' $t$ ', and the rate of change of a country's overall T\&TCI score in two time periods, ' $t$ ' and ' $t-1$ '.

- the rate of change in a country's overall T\&TCI score and the rate of change of a country's market share of inbound tourism expenditures. The model establishes the association between the rate of change in inbound tourism expenditures in time ' $t$ ', and the rate of change of a country's overall T\&TCI score in two time periods, ' $t$ ' and ' $t-1$ '. 
Table 5. Competitive capability and performance indicators

Indicators
$\begin{aligned} & \text { Rate of change of a country's overall T\& } \\ & \left(\% \Delta T \& T C I_{i t}\right)\end{aligned}$
Formula:
$\% \Delta T \& T C I_{i t}=\frac{\frac{T \& T C I_{i t}}{\frac{\sum_{i=1}^{n} T \& T C I_{i t}}{n}}}{\frac{T \& T C I_{i t-1}}{\sum_{i=1}^{n} T \& T C I_{i t-1}}}$

where:

- $T E T C I_{i t}$ is the overall T\&TCI score of the country ' $I$ ' in time ' $t$ '

- $\quad$ ' ' represents each Mediterranean country for which data are available (from 1 to $\mathrm{n}$ )

\section{Explanation}

Competitiveness capability indicator $\left(\% \Delta \mathrm{T} \& \mathrm{TCI}_{\mathrm{t}}\right)$ is defined as the rate of change of a total T\&TCI score of the country ' $i$ ' in two consecutive measurement periods relative to change in the overall T\&TCI score of the Mediterranean region as a whole in same two consecutive measurement periods, in \%; The indicator measures the relative position of a country's competitive capability in relation to other Mediterranean countries. The increase of the indicator indicates a relative improvement in the quality of a country's overall tourism offer compared to other Mediterranean countries;

The change in a country's competitive position is determined for each of the five two-year intervals in the 2007 - 2017 period for which T\&TCI data are available;

The indicator is based on the data published in the World Economic Forum (2009, 2011, 2013, 2015, 2017).

Rate of change of a country's market share of international tourism arrivals $\left(\% \Delta T I A_{i t}\right)$

Formula:

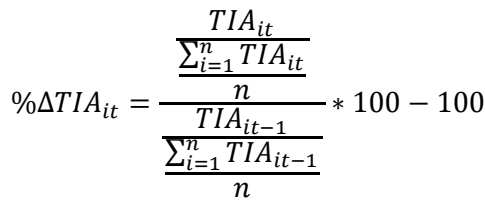

where

- $\quad$ TIA $_{\text {it }}$ represents the number of international tourism arrivals in country ' $i$ ' in time ' $t$ '

- $\quad$ ' ' represents each Mediterranean country for which data are available (from 1 to $\mathrm{n}$ )

Competitive performance indicator $\left(\% \Delta T I A_{i t}\right)$ is defined as a rate of change in international tourism arrivals market share of a country „ $i$ “ within the Mediterranean region in two consecutive measurement periods, in \%;

The indicator measures the relative change in the market position of an individual country within the Mediterranean region (measured by the number of international tourist arrivals);

The increase of the indicator indicates a relative improvement in the competitive position of a country ' $i$ ' regarding the physical volume of tourism flow in the Mediterranean;

The change in the market position is determined for each of the years within the $2007-2017$ period for which the T\&TCI score is available;

The indicator is based on the data published in the UNWTO Compendium of Tourism Statistics for the 2007-2011 period, and for the 2013-2017 period (UNWTO, 2013; UNWTO 2019).

Rate of change of a country's market share of inbound tourism expenditures $\left(\% \Delta I T E_{t}\right)$

Formula:

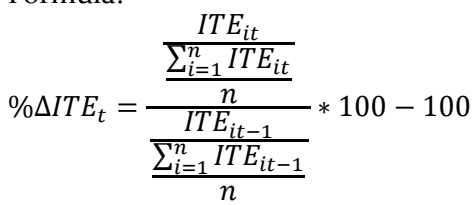

where

- $I T E_{i t}$ represents the inbound tourism expenditures in current US\$ prices in the country $i$ in time ' $t$ '

- $\quad$ ' $i$ represents each Mediterranean country for which data are available (from 1 to $n$ )
Competitive performance indicator $\left(\% \Delta I T E_{t}\right)$ is defined as the rate of change in market share of inbound tourism expenditures of a country ' $i$ ' within the Mediterranean region ' in two consecutive measurement periods, in \%;

The indicator measures the relative change in the market position of an individual country within the Mediterranean region (measured by the amount of inbound tourism expenditures in US\$);

The increase of the indicator indicates a relative improvement in the competitive position of a country ' $i$ ' regarding overall tourism-related financial flows within the Mediterranean;

The change in the market position is determined for each of the years within the $2007-2017$ period for which the T\&TCI score is available;

The indicator is based on the data published in the UNWTO Compendium of Tourism Statistics for the 2007-2011 period, and for the 2013-2017 period (UNWTO, 2013; UNWTO 2019). 
The ordered pairs of T\&TCI score and performance-related indicators for each country are shown in the orthogonal coordinate system in which the first place in the ordered pairs refers to the abscissa axis (rate of change in T\&TCI score), and the second to the ordinate axis (rate of change of a country's market share of international tourism arrivals, or, rate of change of a country's market share of inbound tourism expenditures).

Ordered pairs of relative changes in the T\&TCI score and each of the tourism performance related indicators in the coordinate system generates a scatter diagram that extends over one or more quadrants. Since the coordinate system is divided into four quadrants whose boundaries represent two half-axes with different signs (positive or negative), the ordered pairs can be spread over one or more quadrants depending on the direction of the change (positive or negative). The first quadrant contains ordered pairs in which a positive relative change in a country's T\&TCI score is accompanied by an increase in its market share, either in international tourist arrivals or in inbound tourism expenditures. The third quadrant contains ordered pairs in which a country's negative relative change in the T\&TCI score is accompanied by a decrease in its market share, either in international tourist arrivals, or inbound tourism expenditures.

Ordered pairs of relative changes in the T\&TCI score and each of the tourism performance related indicators located in the second (II) and fourth (IV) quadrants indicate their movement in the opposite direction, which is theoretically illegitimate. In other words, the second and fourth quadrants contain ordered pairs of indicators in which a decrease in the relative change in a country's T\&TCI score is accompanied by an increase in its rate of change in market share measured by either arrivals, or expenditures, and vice versa.

\section{Results and discussion}

Based on the established methodological framework described above, the results of the analysis are presented in Figure 1 and Figure 2.

The analysis indicates that the change in the T\&TCI score for the selected countries throughout the 2007 - 2017 period does not move in unison with the changes in two selected performance-related indicators of tourism activity. In other words, the scatter diagrams indicate that the relative changes in the T\&TCI score, and the relative changes in the market shares of international tourism arrivals/inbound tourism expenditures, for a large number of analyzed countries move in opposite directions throughout the $2007-2017$ period. While some of the countries record a relative decrease in the T\&TCI score, accompanied with a relative increase in the market shares of international tourist arrivals and/or inbound tourism expenditures (quadrant II), other countries, within the same time interval, record a relative increase in the T\&TCI score, accompanied by a relative decrease in the market shares of international tourist arrivals and/or inbound tourism expenditures (quadrant IV). In view of these findings, one can only conclude that the T\&TCI score does not reflect the issue of destination competitiveness on a satisfactory level. Further, the association between the change in the T\&TCI scores and the change in both performance-based indicators fluctuates considerably throughout all four twoyear intervals. This confirms the results presented recently by Hanafiah \& Zulkilfy (2019) in which they demonstrate the existence of inconsistencies in the T\&TCI score and actual tourism performance across 115 countries worldwide. Further, the obtained results are also in line with the earlier findings of Mazanec \& Ring (2011), and Ring (2016), who have demonstrated a rather low relationship between the T\&TCI score and the dynamics in a country's tourism arrivals. 

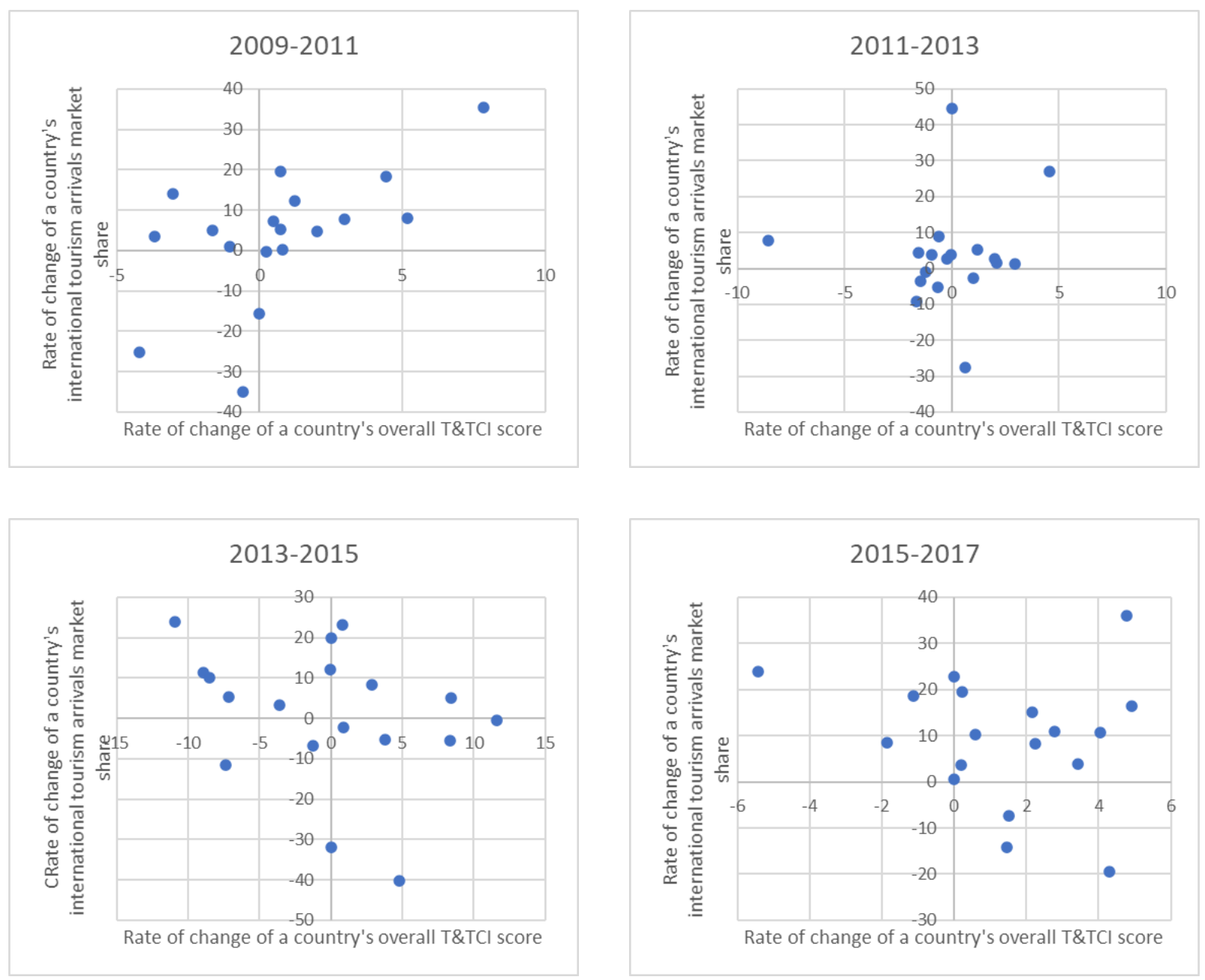

Source: Authors, based on data presented World Economic Forum (2009, 2011, 2013, 2015, 2017), and the UNWTO

(2013, 2019)

Figure 1. Rate of change in a country's overall TETCI score and the rate of change in its international tourist arrivals' market share in time ' $t$ ': ordered pairs in four periods

Despite the rather low level of association between the change in the T\&TCI score and both performance-based indicators of tourism activity, the highest level of association of T\&TCI score and international tourism arrivals has been determined for the 2009 - 2011 period, when 11 out of 17 countries (or $64.7 \%$ ) showed indicator changes in the same direction. The lowest level of association, on the other hand, most probably as a result of the so called 'Arab Spring', has been determined for the $2013-2015$ period, when only 4 of 16 (or $25.0 \%$ ) of the analyzed countries showed same-direction indicator changes. Apart from the low level of association in the direction of indicator movements, the analysis has shown that the T\&TCI score in the previous year was somewhat better associated to the relative changes in international tourism arrivals for most of the 2007 - 2017 period (Table 4). This is not surprising since the positive change in the T\&TCI score in the previous year, as an overall indicator of the improved quality of the total tourism-related offer within a destination, should positively affect the level of 
tourism demand over an extended time in the future. Nevertheless, the degree of association between the relative changes in tourist arrivals and the T\&TCI score in the previous period also fluctuates considerably during the whole of the $2007-2017$ period. For example, in the $2011-2013$ period, as many as 13 of the 17 countries (or a high 76.5\%) recorded indicator changes in the same direction. The lowest degree of direction compatibility was recorded in the 2015 - 2017 period, when only 6 out of the 16 countries (or $37.5 \%$ ) showed indicator movements in the same direction.
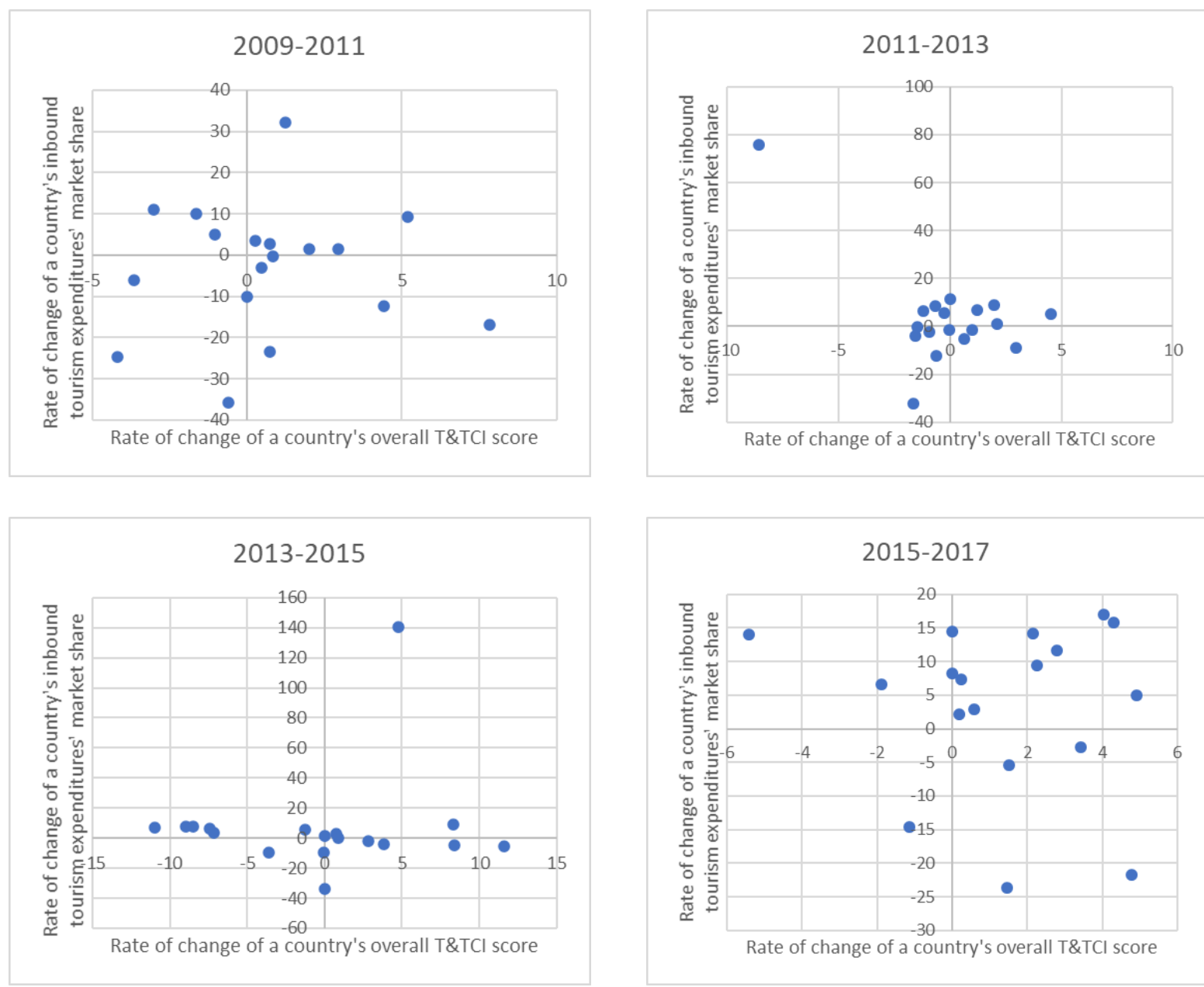

Source: Authors, based on data presented World Economic Forum (2009, 2011, 2013, 2015, 2017), and the UNWTO $(2013,2019))$

Figure 2. Rate of change of a country's overall TETCI score and rate of change of a country's inbound tourism expenditures' market share in time ' $t$ ': ordered pairs in four periods

On the other hand, the highest level of direction coincidence between the change of T\&TCI scores and the inbound tourism expenditures (Table 5) has been recorded for the 2015 - 2017 period, when 10 out of 17 countries (or $58.8 \%$ ) showed the same direction of change. The lowest level of direction coincidence, as in the case of arrivals, has been recorded during the $2013-2015$ period, when only 6 out of 16 countries (or $37.5 \%$ ) showed same-direction indicator changes. However, in contrast to the 
situation with the international tourist arrivals, a higher degree of direction coincidence of the T\&TCI scores, and inbound tourism expenditures has been recorded when both indicators addressed the changes in the same year. This can be explained by the fact that the increase in quality of the total tourism-related offer in a destination (as measured by the change in the T\&TCI score) in any given year should simultaneously be reflected in the increased tourist spending.

Table 4. Analyzed Mediterranean countries according to the direction of a relative change in international tourism arrivals, and the TETCI score

\begin{tabular}{|c|c|c|c|c|c|}
\hline & \multicolumn{3}{|c|}{$\begin{array}{l}\text { Number of countries where the relative } \\
\text { change of international tourism arrivals, } \\
\text { and the relative change in the T\&TCI } \\
\text { score moved in the same direction }\end{array}$} & \multicolumn{2}{|c|}{$\begin{array}{l}\text { Number of countries where the } \\
\text { relative change of international } \\
\text { tourism arrivals, and the relative } \\
\text { change in the T\&TCI score moved in } \\
\text { the opposite direction }\end{array}$} \\
\hline & $T \& T C I$ in period $t$ & $\begin{array}{l}\text { T\&TCI in } \\
t-1\end{array}$ & period & $T \& T C I$ in period $t$ & $\begin{array}{l}\text { T\&TCI in period } \\
t-1\end{array}$ \\
\hline \multicolumn{6}{|l|}{ Total \# of countries } \\
\hline $2011 / 2009$ & 11 & 12 & & 6 & 5 \\
\hline $2013 / 2011$ & 8 & 12 & & 9 & 5 \\
\hline $2015 / 2013$ & 4 & 8 & & 12 & 8 \\
\hline $2017 / 2015$ & 10 & 6 & & 7 & 10 \\
\hline $\begin{array}{l}\text { Average for the 2009- } \\
2017 \text { period (in \%) }\end{array}$ & 48,9 & 57, & & 51,1 & 42,8 \\
\hline
\end{tabular}

Source: Authors, based on data presented by the World Economic Forum (2009, 2011, 2013, 2015, 2017), and the UNWTO (2013, 2019)

Table 5. Analyzed Mediterranean countries according to the direction of a relative change in inbound tourism expenditures and the TETCI score

\begin{tabular}{|c|c|c|c|c|}
\hline & \multicolumn{2}{|c|}{$\begin{array}{l}\text { Number of countries where the relative } \\
\text { change of inbound tourism } \\
\text { expenditures, and the relative change } \\
\text { in the T\&TCI score moved in the same } \\
\text { direction }\end{array}$} & \multicolumn{2}{|c|}{$\begin{array}{l}\text { Number of countries where the relative } \\
\text { change of inbound tourism } \\
\text { expenditures, and the relative change } \\
\text { in the T\&TCI score moved in the } \\
\text { opposite direction }\end{array}$} \\
\hline & $T \& T C I$ in period $t$ & $\begin{array}{l}\text { T\&TCI in period } \\
t-1\end{array}$ & $T \& T C I$ in period $t$ & $\begin{array}{l}\text { T\&TCI in period } \\
t-1\end{array}$ \\
\hline \multicolumn{5}{|l|}{ Total \# of countries } \\
\hline $2011 / 2009$ & 9 & 9 & 8 & 8 \\
\hline $2013 / 2011$ & 9 & 5 & 8 & 12 \\
\hline $2015 / 2013$ & 6 & 7 & 10 & 9 \\
\hline $2017 / 2015$ & 10 & 4 & 7 & 12 \\
\hline $\begin{array}{l}\text { Average for the 2009-2017 } \\
\text { period (in \%) }\end{array}$ & 50.6 & 37.8 & $49 \cdot 4$ & 62.2 \\
\hline
\end{tabular}

Source: Authors, based on data presented by the World Economic Forum (2009, 2011, 2013, 2015, 2017), and the

UNWTO (2013, 2019)

\section{Concluding remarks}

Even though it represents a straightforward, pragmatic and, therefore, widely used approach to destination competitiveness measurement, the T\&TCI approach disregards most of the recommendations provided by the destination competitiveness theory. Further, the methodology on which the T\&TCI is constructed is characterized by numerous shortcomings which undermine not only the validity of its use, but the reliability of its results as well. This paper revealed both facts. 
Based on the assumption that the T\&TCI score relates rather well to the real, statistically measured indicators of tourism activity within a destination, a simple and straightforward analysis has been carried out on the Mediterranean countries over a 2007 - 2017 period. Using international arrivals and inbound tourism expenditures as proxies of performance-related tourism activity within a destination, it has been shown that a positive or negative change in the T\&TCI score of a country is matched in only half of the countries by the movement of the proxy variables in the same direction. It has, therefore, been concluded that this low matching in direction of movement signifies the lack of reliability of the T\&TCI score as a reliable measure of a destination's competitiveness. Further, mostly due to different consumer behavior patterns, it has also been found that the T\&TCI scores relate differently to changes of the relevant indicators of tourism activity in different time intervals.

Although the idea of the paper was not to suggest ways to improve the reliability of the index itself, the limited ability of the T\&TCI score to explain real life movements in tourism activity within a destination asks for further refinements in the T\&TCI methodology. These refinements should especially address the following issues:

- the inclusion of a set of tourist experience-related indicators into the index;

- the replacement of certain, either inadequately chosen, or utterly biased indicators that are currently used as proxies for various aspects of a destination's integral tourism offer, especially in relation to the less developed countries;

- allowing more flexibility to the index, especially to provide better indications of destination competitiveness among countries which, based on their tourism product distinctive features, can be regarded as competitors to each other;

- replacement of the current system of applying equal weights to each of the indicators, pillars and /or sub-indices so as to ensure a more realistic approach capable of capturing the behavior of contemporary consumers in a more adequate way.

The suggested modifications of the present T\&TCI approach and structure should aim to ensure a less volatile and more consistent correlation with real, performance-based, tourism aggregates for each country. In this regard, further, more attention should be devoted to the time dimension, as well as to the size of the countries involved in the analysis.

Finally, providing necessary modifications or refinements to the T\&TCI approach will continue to be made, the methodological approach suggested in this paper can still be used to verify the improvement of the T\&TCI score's ability to explain the real, performance-based indicators of tourism activity within a destination.

\section{References}

Abreu-Novais, M., Ruhanen, L., \& Arcodia, C. (2016). Destination competitiveness: What we know, what we know but shouldn't and what we don't know but should. Current Issues in Tourism, 19(6), 492512.

Abreu-Novais, M., Ruhanen, L., \&. Arcodia, C. (2018). Destination competitiveness: A phenomenographic study. Tourism Management, 64, 324-334.

Aral-Tur, A., \& Kozak, M. (2015). Introduction. In Aral-Tur, A., \& Kozak, M. (eds) Destination competitiveness, the environment and sustainability: challenges and cases, Oxfordshire, Boston MA: CABI, 1-9. 
Assaf, A. G., \& Tsionas, E. M. (2015). Incorporating destination quality into the measurement of tourism performance: A Bayesian approach. Tourism Management 49(C), 58-71.

Ateljevic, I. (2000). Circuits of Tourism. Stepping Beyond the 'Production/Consumption' Dichotomy. Tourism Geographies, 2(4), 369-88.

Baerenholdt, J. O., M. Haldrup, J. Larsen, \& J. Urry (2004). Performing Tourist Places: New Directions in Tourism Analysis Series. Aldershot: Ashgate.

Balan, D., Balaure, V., \& Veghes, C. (2009). Travel and tourism competitiveness of the world's top tourism destinations: an exploratory assessment. Annals Universitatis Apulensis Series Oeconomica, 11(2), 979-987.

Bednarova, L., Kiselakova, D., \& Onuferova, E. (2018). Competitiveness analysis of tourism in the European union and in Slovakia. GeoJournal of Tourism and Geosites, 23(3), 759-771.

Beritelli, P., Bieger, T., \& Laesser, C. (2007). Destination governance. Usingcorporate governance theories as a foundation for effective destination management. Journal of Travel Research, 46(1), 96-107.

Buhalis, D. (2000). Marketing the Competitive Destination of the Future. Tourism Management, 21(1), 97-116.

Croes, R. (2011). Measuring and explaining competitiveness in the context of small island destinations. Journal of Travel Research, 50(4), 431-442

Croes, R., \& Kubickova, M. (2013). From potential to ability to compete: Towards a performance-based tourism competitive index. Journal of Destination Marketing \& Management, 2(3), 146-154

Croes, R., \& Semrad, K. (2018). Destination Competitiveness. In Cooper, C., Volo, S., Gartner, W., \& Noel, S. (eds) The Sage handbook of Tourism Management, Sage, 77-90

Crouch, D. (1999). Leisure/Tourism Geographies: Practices and Geographical Knowledge. Critical Geographies Series. London: Routledge.

Crouch, G.I. (2007). Measuring tourism competitiveness. Research, theory and the WEF Index. Proceedings of the ANZMAC 2007, 3-5 December, Dunedin, New Zealand.

Crouch, G.I., \& Ritchie, J.R.B. (1999). Tourism, competitiveness, and societal prosperity. Journal of Business Research, 44(3), 137-152.

Cucculelli, M., \& Goffi, G. (2016). Does sustainability enhance tourism destination competitiveness? Evidence from Italian Destinations of Excellence. Journal of Cleaner Production, 111(B), 370-382.

Cvelbar, L., Dwyer, L., Koman, M., \& Mihalic, T. (2016). Drivers of destination competitiveness in tourism: A global investigation. Journal of Travel Research, 55(8), 1041-1050.

Dolnicar, S. (2019). Market segmentation analysis in tourism: a perspective paper, Tourism Review, Vol. 75 No. 1, 45-48.

Dupeyras, A., \& MacCallum, N. (2013). Indicators for Measuring Competitiveness in Tourism: A Guidance Document. OECD Tourism Papers, 2013/o2. Paris: OECD Publishing.

Dwyer, L., \& Kim, C. (2003). Destination Competitiveness: Determinants and Indicators. Current Issues in Tourism, 6(5), 369-414.

Dwyer, L., Mellor, R., Livaic, Z., Edwards, D., \& Kim, C. (2004). Attributes of destination competitiveness: A factor analysis. Tourism Analysis, 9(1-2), 91-101.

Dwyer, L., Edwards, D., Mistilis, N., Roman, C., \& Scott, N. (2009). Destination and enterprise management for a tourism future. Tourism Management, 30(1), 63-74.

Dwyer, L., Forsyth, P., \& Dwyer, W. (2011). The travel and tourism competitive index as a tool for economic development and poverty reduction. Strategic Management in Tourism, 33-52.

Dwyer, L., Dragićević, V., Armenski, T., Mihalič, T., \& Knežević Cvelbar, Lj. (2016). Achieving destination competitiveness: an importance-performance analysis of Serbia. Current Issues in Tourism, 19(13), 1309-1336. 
Enright, M. J., \& Newton, J. (2004). Tourism Destination Competitiveness: A Quantitative Approach. Tourism Management, 25(6), 777-788.

Enright, M. J., \& Newton, J. (2005). Determinants of Tourism Destination Competitiveness in Asia Pacific: Comprehensiveness and Universality. Journal of Travel Research, 43(4), 339-350.

Garelli, S. (2006). Competitiveness of Nations: The Fundamentals. IMD World Competitiveness Yearbook.

Goeldner, R., Ritchie, J., \& McIntosh, R. (200o). Tourism. Principles, Practices, Philosophies, 8th edition. New York: John Wiley \& Sons.

Goffi, G. (2013). Tourism destination competitiveness: Theoretical models and empirical evidence. (Doctoral dissertation). Retrieved from Research Gate.

Gnoth, J. (2007). The Structure of Destination Brands: Leveraging Values. Tourism Analysis, 12(5-6), 34568.

Goeldner, R., Ritchie, J., \& McIntosh, R. (200o). Tourism. Principles, Practices, Philosophies, 8th edition. New York: John Wiley \& Sons.

Gonzales M. A., \& Bello, L. (2002). The construct 'lifecycle' in market segmentation: The behavior of tourist consumers. European Journal of Marketing, 36(1/2), 51-85.

Gooroochurn, N., \& Sugiyarto, G. (2005). Measuring Competitiveness in the Travel and Tourism Industry. Tourism Economics, 11(1), 25-43.

Guaita Martinez, J. M., Martin, J. M., \& Salinas Fernandez, J. A: (2020). Innovation in the Measurement of Tourism Competitiveness. In Analyzing the Relationship Between Innovation, Value Creation, and Entrepreneurship: IGI GLOBAL, 266-288.

Hall, C. M., \& Page, S. J. (2006). The Geography of Tourism E Recreation. Environment, Place and Space, 3rd edition. London: Routledge.

Hall, C. M. (2007). Tourism and regional competitiveness. In Tribe, J., Airey, D. (ed.) Developments in Tourism Research. Amsterdam: Elsevier, 217-230.

Hanafiah, M. H., Hemdi, M. A., \& Ahmad, I. (2015). Reflections on Tourism Destination Competitiveness (TDC) Determinants. Advanced Science Letters, 21(5), 1571-1574.

Hanafiah, M. H., \& Zulkilfly, M. I. (2019). Tourism Destination competitiveness and tourism performance: A secondary data approach. Competitiveness Review: An International Business Journal, 29(5), 592-621.

Hassan, S. (2000). Determinants of market competitiveness in an environmentally sustainable tourism industry. Journal of Travel Research, 38(3), 239-245.

Haugland, S. A., Ness, H., Gronseth, B. O., \& Aarstad, J. (2011). Development of Tourism Destinations: An integrated Multilevel Perspective. Annals of Tourism Research, 38(1), 268-290.

Heath, E. (2003). Towards a model to enhance destination competitiveness: a South African perspective. Journal of Hospitality and Tourism Management, 10(2), 124-141.

Ivanov, S., \& Webster, C. (2013). Tourism's impact on growth: The role of globalisation. Annals of Tourism Research 41, 231-236.

Ivanov, S., \& Ivanova, M. (2016). Do hotel chains improve destination's competitiveness? Tourism Management Perspectives, 19(A), 74-79.

Jackman, M., Lorde, T., Lowe, S., \& Alleyne, A. (2011). Evaluating tourism competitiveness of small island developing states: a revealed comparative advantage approach. Anatolia, 22(3), 350-360.

Kayar, C. H., \& Kozak, N. (2010). Measuring Destination Competitiveness: An Application of the Travel and Tourism Competitiveness Index (2007). Journal of Hospitality Marketing E Management 19(3), 203-216.

Kester, J., \& Croce, V. (2011). Tourism development in advanced and emerging economies: what does the travel and tourism competitiveness index tell us. The Travel and Tourism Competitiveness Report, 45-52. 
Kunst, I. (1998). Tržišna strukturiranost hrvatskog turističkog sektora. Turizam, 46(3), 123-139.

Kunst, I. (2009). Tourism destination competitiveness assessment - approach and limitations. Acta turistica, 21(2),129-159.

Kunst, I. (2011). The role of government in promoting tourism investment in selected Mediterranean countries - implications for the Republic of Croatia. Tourism and Hospitality Management, 17(1), 115-130.

Kunst, I. (2017). Image redesign as a tool for safeguarding destination's market prosperity: The case of Dubrovnik. Sociologija i prostor, 55(1), 55-74.

Lall, S. (2001). Competitiveness indices and developing countries: An economic evaluation of the Global Competitiveness Report. World Development, 29(9), 1501-1525.

Leiper, N. (1995). Tourism Management. Melbourne: RMIT Press.

Magrini, A., \& Grassini, L. (2020). The determinants of tourism destination competitiveness in 2006 2016: A partial least squares path modelling approach. Italian Journal of Applied Statistics, 31(2), 251-269.

Mangion, M.-L., Durbarry, R., \& Sinclair, M. T. (2005). Tourism Competitiveness: Price and Quality. Tourism Economics, 11(1), 45-68.

Marti, L., \& Puertas, R. (2017). Determinants of tourist arrivals in European Mediterranean countries: Analysis of competitiveness. European Journal of Tourism Research 15, 131-142.

Mazanec, J., Woerber, K., \& Zins, A. H. (2007). Tourism Destination Competitiveness: From Definition to Explanation? Journal of Travel Research, 46(1), 86-95. •

Mazanec, J., \& Ring, A. (2011). Tourism destination competitiveness: second thoughts on the World Economic Forum reports. Tourism Economics, 17(4), 725-751.

Mendola, D., \& Volo, S. (2017). Building composite indicators in tourism studies: Measurements and applications in tourism destination competitiveness, Tourism Management, 59, 541-553.

Morrison, A. (2013). Destination management and destination marketing: The platform for excellence in tourism destinations. Tourism Tribune, 28(1), 6-9.

Murphy, P., Pritchard, M., \& Smith, B. (2000). The destination product and its impact on traveler perceptions. Tourism Management, 21(1), 43-52.

Pearce, D. (1989). Tourism Development, 2nd edition. Essex: Longman.

Pine, J. B., \& Gilmore, J. H. (1998). Welcome to the experience economy. Harvard Business Review, JulyAugust.

Pine, J. B., \& Gilmore, J. H. (1999). The experience economy. Boston: Harvard Business School Press.

Porter, M. E. (1980). Competitive Strategy, Techniques for Analyzing Industries and Competitors. New York: The Free Press.

Porter, M. E. (1990). The Competitive Advantage of Nations. London: The McMillan Press.

Pritchard, A., \& Morgan. N. (2001). Culture, Identity and Tourism Representation: Marketing Cymru or Wales? Tourism Management, 22(2), 167-179.

Ring, A. (2016). Alternative models within the framework of the World Economic Forum's Travel \& Tourism Competitiveness Index - Suggestions for theory development. Travel and Tourism Research Association: Advancing Tourism Research Globally.

Ritchie, J. R. B., \& Crouch, G. I. (2005). The Competitive Destination, A Sustainable Tourism Perspective. Oxford: Oxford University Press.

Rodriguez-Diaz, M., \& Espino-Rodrıguez, T. F. (2008). A model of strategic evaluation of a tourism destination based on internal and relational capabilities. Journal of Travel Research, 46(4), 368380.

Salinas Fernandez, J. A., Azevedo, P. S., Martin Martin, J. A., \& Rodriguez Martin, J. A. (2020). Determinants of tourism destination competitiveness in the countries most visited by 
international tourists: Proposal of a synthetic index. Tourism Management Perspectives, 33, page undefined (Retrieved from Science Direct).

Sargent, T., \& Lucas, R. (1981). Rational expectations and econometric practice. Minneapolis: University of Minnesota Press.

Song, H., Liu, J., \& Chen, G. (2013). Tourism Value Chain Governance: Review and Prospects. Journal of Travel Research, 52(1), 15-28.

Squalli, J., Wilson, K., \& Hugo, S. (2008). An analysis of growth competitiveness. International Review of Applied Economics, 22(1), 105-126.

Sung, J-K., Chang, K. C., \& Sung, Y-F. (2016). Market Segmentation of International Tourists Based on Motivation to Travel: A Case Study of Taiwan. Asia Pacific Journal of Tourism Research, 21(8), 862882.

Tomljenović, R., \& Kunst, I. (2014). From sun and sea tourism to cultural tourism - the case of SplitDalmatia county. European Journal of Tourism Research, 8, 83-98.

Trauer, B. (2006). Conceptualizing special interest tourism - frameworks for analysis. Tourism Management, 27(2), 183-200.

World Tourism Organization [UNWTO] (2019). International Tourism Highlights. Madrid: World Tourism Organization (UNWTO).

Urry, J. (1990). The Tourist Gaze. London: Sage.

UNWTO (2019). Tourism Highlights.

Webster, C., \& Ivanov, S. (2014). Transforming competitiveness into economic benefits: Does tourism stimulate economic growth in more competitive destinations? Tourism Management, 40, 137-140.

Weiermeier, K. (2006). Prospects for Innovation in Tourism: Analyzing the Innovation Potential Throughout the Tourism Value Chain. Journal of Quality Assurance in Hospitality \& Tourism, 6(34), 59-72.

Weldearegay, H. G. (2017). The Determinants of Tourism Destination Competitiveness: PLS Path Model of Structural Equation Modelling, Journal of Tourism \& Hospitality, 6(5), 1-9.

World Economic Forum (2007). The Travel \& Tourism Competitiveness Report. Geneva: World Economic Forum.

World Economic Forum (2008). The Global Competitiveness Report 2008-2009. Geneva: World Economic Forum.

World Economic Forum (2009). The Travel and Tourism Competitiveness Report 2009. Geneva: World Economic Forum.

World Economic Forum (2011). The Travel and Tourism Competitiveness Report 2011. Geneva: World Economic Forum.

World Economic Forum (2013). The Travel and Tourism Competitiveness Report 2013. Geneva: World Economic Forum.

World Economic Forum (2015). The Travel and Tourism Competitiveness Report 2015. Geneva: World Economic Forum.

World Economic Forum (2017). The Travel and Tourism Competitiveness Report 2017. Geneva: World Economic Forum.

World Economic Forum (2019). The Travel and Tourism Competitiveness Report 2019. Geneva: World Economic Forum.

World Economic Forum (1991). World Competitiveness Report. Geneva: World Economic Forum.

World Tourism Organization [UNWTO] (2013). Compendium of Tourism Statistics, Data 2007 - 2011, 2013 Edition. Madrid: World Tourism Organization [UNWTO].

World Tourism Organization [UNWTO] (2019). Compendium of Tourism Statistics, Data 2013 - 2017, 2019 Edition. Madrid: World Tourism Organization [UNWTO]. 
Wu, W-W., Lan, L. W., \& Lee, Y-T. (2012). Critiquing the World Economic Forum's concept of destination competitiveness: A further analysis. Tourism Management Perspectives, 4, 198-206.

Yilmaz, Y., \& Bititci, U. S. (2006). Performance measurement in tourism: a value chain model. International Journal of Contemporary Hospitality Management, 18(4), 341-349.

Received: 14/04/2020

Accepted: 10/o6/2020

Coordinating editor: Stanislav Ivanov 